\title{
Aerial Bud Bank and Structural Changes of Woody Species from Argentine Chaco in Response to Disturbances
}

\author{
Sandra Bravo ${ }^{1}$, María Basualdo ${ }^{2}$, Carlos Kunst ${ }^{3}$ and Florencia del Corro ${ }^{1,4}$ \\ 1. Cátedra de Botánica General, Facultad de Ciencias Forestales, Universidad Nacional de Santiago del Estero, Santiago del Estero, \\ ZC: 4200, Avenida Belgrano 1912 (S), Argentina \\ 2. Cátedra de Ecología, Facultad de Ciencias Forestales, Universidad Nacional de Santiago del Estero, Santiago del Estero, ZC: \\ 4200, Avenida Belgrano 1912 (S), Argentina \\ 3. Instituto Nacional de Tecnología Agropecuaria. Santiago del Estero, ZC: 4200, Jujuy 850, Argentina \\ 4. Consejo Nacional de Investigaciones Científicas y Técnicas CONICET, Santiago del Estero, ZC: 4200, Ruta 9, El Zanjón, \\ Argentina
}

\begin{abstract}
The objectives of this work were to estimate the ABB (Aerial Bud Bank) size in small individuals of four native woody species and its relationship with structural changes of plants after disturbances. Study area was located in dry forests from Western Chaco region, Argentina. Three tree species: Aspidosperma quebracho-blanco (Apocynaceae), Schinopsis lorentzii (Anacardiaceae), Sarcomphalus mistol (Rhamnaceae) and a shrubby species, Schinus fasciculatus (Anacardiaceae) were selected for this study. Twenty (20) juvenile individuals (below $6 \mathrm{~cm}$ diameter) were randomly sampled from each species and plant height (m), diameter (cm) and plant cover (\%) were recorded. ABB was estimated by counting of all growth modules (shoots/branches and thorns) identified in a $1 \mathrm{~m}$ length segment of main stem. Results of an ANOVA (Analysis of Variance) showed significant effects of species $(p<0.0001)$, number of shoots/branches $(p<0.05)$ and number of thorns $(p<0.05)$ on ABB. Schinopsis lorentzii and $S$. fasciculatus were categorized as high ABB species, $S$. mistol and A. quebracho-blanco as medium and low ABB species, respectively. ABB size diminished in all species studied when plant height $(p=0.0006)$ and plant cover $(p<0.0001)$ increased which could be related to most allocation of resources towards height growth and elongation of growth modules rather than to the differentiation of new shoots. A correspondence analysis of ABB size, growth habit, number of sprouts/resprouts, presence of thorns in studied species growing in forests with different disturbances history, showed that perturbations increased number of resprouts, shrubby growth habit but spinescence was only trait with significant association with disturbed areas. These results enhance the knowledge of resprouting pattern after disturbances of native woody species and open new research lines for futures studies.
\end{abstract}

Key words: $A B B$, architectural changes, woody species, disturbances.

\section{Introduction}

Bud bank is defined as the pool of buds available for resprouting on bole and branches including those formed adventitiously only after injury [1]. Individuals of the same species can exhibit great differences in the number of dormant buds, in its

Corresponding author: Sandra Bravo, Ph.D., research fields: fire ecology, regeneration strategies in woody species. disturbances. vertical distribution and ability to produce new shoots and leaves after disturbances [2].

Plants recover biomass to expense from buds and other undamaged meristematic tissues. This strategy is known as resprouting capability and it is partially responsible for resilience of plant communities after disturbances [1-3]. In woody species, resprouting after disturbances can produce changes in the growth habit, in types and proportion of different growth modules and in processes such as assimilation rates and 
allocation of energy resource [4]. The resprouting ability usually decreases with ageing due to combination of genetic, physiological and anatomical changes [5]. However, this trait could vary broadly in different growth forms coexisting in the same unit vegetation [6]. The ability to form adventitious buds in underground organs enhances the resprouting even in adult trees [7, 8]. The intensity, season and frequency of fires can influence the bud expression in different type growth modules [2, 9]. More recently, a new conceptual framework mentioned the bud bank localization, the protection of buds and resource location as controlling factors of resprouting strategy [3].

The overgrazing, logging, deforestation and fires are the most common disturbances of the Argentine Chaco forests [10-12]. Fire is used from pre-Colombian times to promote new growth of grasses and to control shrubby encroachment in Chaco savannas [13]. Silvopastoral systems in native Chaco forests involve management roller-chopping as mechanical removal method of shrubby vegetation, combined with prescribed fires to diminish woody residues and to control shrub encroachment [14]. These disturbances produce loss of aerial structures in seedlings and low diameter individuals of native woody species which resprout from epicormic, basal and/or adventitious buds [7, 9, 15].

The knowledge about bud bank size in small individuals and types of growth modules that they produce could enhance interpretation of resprouting pattern after disturbances. Authors considered the following hypothesis: (a) species differ in bud bank size and resprouting ability, (b) small size individuals have greater bud bank than bigger size individuals, and (c) disturbances modify the tree growth habit of species, according to the bud bank size. The first hypothesis reflected previous findings indicating a high variability in resprouting ability among woody species $[2,16,17]$. The second hypothesis considered that small size individuals show greater number of resprouts due to high vigor and low energy destined to maintenance of aerial organs $[9,18]$. The third hypothesis reflected antecedents indicating that woody species experiment architectural changes after disturbances such as fires, roller-chopping and browsing, increasing the number of shoots [19, 20], and promoting basal resprouting after high severity disturbances $[9,15]$. The objective of this work was to estimate the ABB (Aerial Bud Bank) size in seedlings and small size individuals of four native woody species from Argentine Chaco, to identify types of growth modules and structural responses to disturbances.

\section{Materials and Methods}

\subsection{Field Work}

The study area is located in Western Argentine Chaco region, in the Campo Experimental Francisco Cantos, belonging to the INTA (Instituto Nacional de Tecnología Agropecuaria), Santiago del Estero $\left(28^{\circ} 03^{\prime}\right.$ $\mathrm{S} 64^{\circ} 15^{\prime} \mathrm{E}$ ) (Fig. 1, [16]). Climate is semiarid, with an annual average rainfall of $574 \mathrm{~mm}$ (1934-2000 series, INTA Santiago del Estero Experimental Station, 2010). Winters are cold and dry, and summers hot and rainy. Mean annual temperature is $19.8{ }^{\circ} \mathrm{C}$, and the mean temperatures of the warmest (January) and coldest (July) months are $26.1{ }^{\circ} \mathrm{C}$ and $10.6{ }^{\circ} \mathrm{C}$, respectively [10]. Soils belong to the order Entisols, suborder Eutric Regosol.

Images taken from UMSEF (Unidad de Manejo del Sistema de Evaluación Forestal) Dirección Forestal (2003).

The native vegetation of the Chaco region of Argentina is composed of a mosaic of thorny semideciduous forests, woodlands, savannas and shrublands. Schinopsis lorentzii (Griseb.) Engler, Anacardiaceae (quebracho colorado santiagueño) and Aspidosperma quebracho-blanco (Schelcht) Apocynaceae (quebracho blanco) dominate in upper layers of the forests (above $20 \mathrm{~m}$ tall). Prosopis nigra (algarrobo negro), Sarcomphalus mistol (Griseb.) 


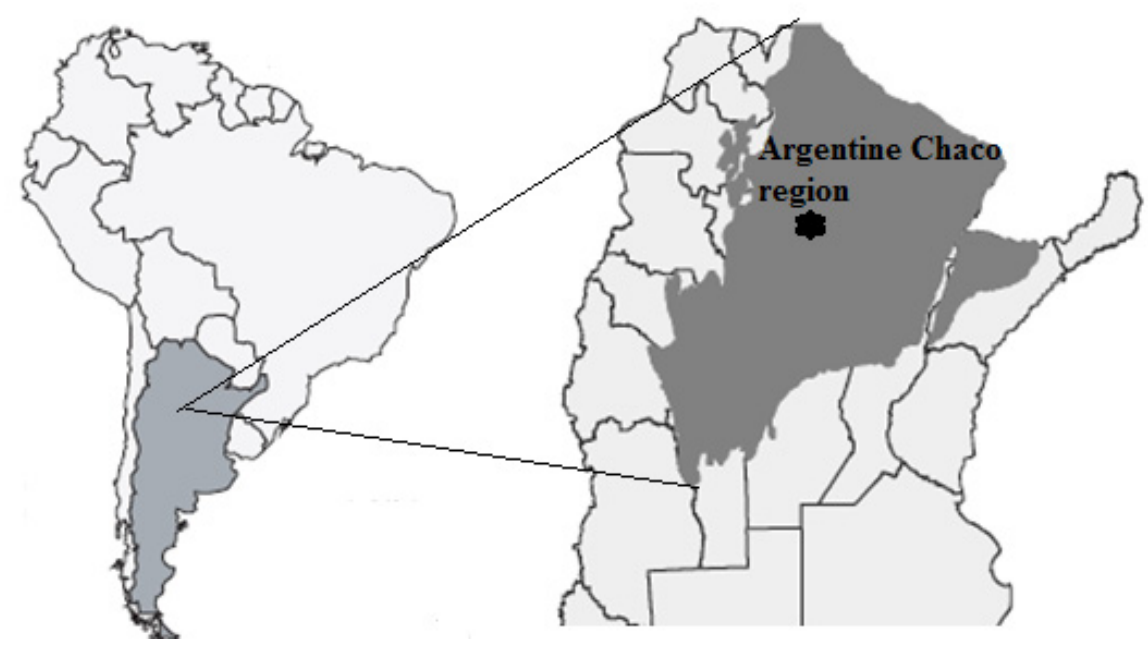

Fig. 1 Localization of study area in Western Argentine Chaco region.

Hauenschild, Rhamnaceae (mistol), Cercidium praecox (brea), and Geoffroea decorticans (chañar) are common species in the medium strata. Schinus fasciculatus, Anacardiaceae (molle), Jodina rhombifolia (sombra de toro), Condalia microphylla (piquillín), Vachellia aroma (Ex. Acacia aroma), Senegalia gilliessi (Ex. Acacia furcatispina) and Atamisquea emarginata dominate the shrubby strata $[21,22]$. These forests have extensive ecotones with savannas where usually wildfires start and local cattlemen burn pastures to promote new growth of grasses. Over the last century, fires occurred with different frequency within Chaco region savannas, with average fire intervals of 3.38 years [11]. The fire frequency increased from 70's decade influenced by greater water availability at regional level. Fires arrive to forests depending on amount and desiccation level of fine fuel [22]. The extensive livestock activity is other common disturbance within Chaco forests and the grazing intensity is usually unknown in the most areas with native forests.

Authors selected for this study three tree species with great ecological and productive importance: $A$. quebracho-blanco, S. lorentzii, S. mistol, and a shrubby species considered as one of the most problematic to control in disturbed areas: $S$. fasciculatus, Anacardiaceae. Schinopsis lorentzii is an endemic hardwood species in Western Chaco region, with valuable wood and currently it is included in IUCN (International Union for Conservation of Nature and Natural Resources) Red List of Threatened Species. Aspidosperma quebracho-blanco is valuable hardwood species for restoration activities due to its rusticity and a wide distribution area. Sarcomphalus mistol dominates medium stratum of native Chaco forests and it produces edible fruits. Schinus fasciculatus is a common component of forest shrubby stratum which becomes dominant in forests severely disturbed by logging, overgrazing or wildfires [22].

\subsection{ABB Estimation}

There is little agreement about methods for bud bank evaluations. The counting of all buds in woody species seems impossible because it is a high time consuming technique and an uncertain number of buds could remain deeply included in secondary tissues and/or below-ground organs, as well as adventitious buds can be differentiated [2]. An axillary bud can develop a long shoot, a braquiblast, a short spiny shoot or a floral axis depending on development stage and disturbances. The counting of growth modules produced by main bole of woody species could be considered as an indirect method for estimating the bud bank size at least among juvenile individuals in 
which bark thickness does not avoid or hamper expression of aerial buds. The study of growth modules types that species can produce from the aerial organs could contribute to predicting the resprouting ability, defensive strategy on new shoots, recovery of functional processes and plant survival after disturbances [4].

Sampling was carried out at early autumn when all growth modules differentiated during previous growth season are completely developed. At this time, woody plants usually start their growth recess period (from May to October) due to the dryness and cold temperatures in Western Chaco region. Authors randomly sampled 20 individuals below $6 \mathrm{~cm}$ diameter of each species selected for this study. This diameter range is considered within the range including seedlings and advanced regeneration [21]. The plant cover was determined by the canopy projection on ground, recording diameter(s) of circumference or ellipse axes for the area assessment.

In order to estimate the $\mathrm{ABB}$, a $1 \mathrm{~m}$ length basal segment of main bole from each tree or shrub, including branches, thorns and foliage was extracted. The selection of this bole segment considered that: (a) the bud bank available to resprout develops on perennial aerial or underground organs, and (b) a preliminary field monitoring indicated that most resprouts in juvenile individuals are located at this level of plants. Main bole segments were analyzed at laboratory recording the number of vegetative growth modules (sprouts, resprouts and thorns) and the number and length of thorns, considering each one as the expression of a bud. The growth modules number on lateral ramifications was not considered. $\mathrm{ABB}$ of each individual (ABB) was estimated by the sum of all vegetative growth modules expressed in the main bole segment extracted. The length of thorns $(\mathrm{cm})$ and the frequency of branched thorns were registered considering their relationship with plant cover and the defensive significance of this trait [24]. The thorn length was measured by digital caliper with $0.001 \mathrm{~cm}$ precision and an average thorn length of each individual was obtained.

\subsection{Relation between ABB and Structural Changes}

The relationship between the ABB size of species studied and growth habit (shrub or tree), resprouting intensity and spinescence was tested in individuals growing in two forest types with different disturbance histories in the same study area: (a) forests under closure (without wildfires and livestock since three last decades), considering them as control plots and, (b) forests disturbed by wildfires and livestock over the last decade. The wildfires signals as fire scars, charred barks, and carbonized wood allowed us to identify past fires though dates of these events are unknown. Similarly, animal stools and signals such as broken branches and consumed leaves indicated us herbivory existence but we did no dispose certain data about its intensity.

Four $50 \times 50 \mathrm{~m}$ plots were located in each type of native forest. In each plot, three $50 \mathrm{~m}$ length transects were emplaced with $5 \mathrm{~m}$ of distance among them. Authors recorded the growth habit, resprouting intensity and presence of thorns in all individuals intercepted by transects, with plant height above 10 $\mathrm{cm}$ of the four species selected for ABB study. Functional traits were categorized as according to Muller, et al. [25]: growth habit $(1=$ sub shrub, $2=$ shrub and $3=$ tree), ABB size (low, medium and high, tacking account the values obtained by early study), resprouting intensity (high $\geq 7$ shoots on the main bole, low $\leq 7$ shoots and null = only main bole), and thorn presence as binary trait $(1=$ present and $0=$ null $)$.

\subsection{Statistical Analysis}

In order to characterize the $\mathrm{ABB}$ size of four species studied and types of growth modules, authors performed an ANOVA with $\mathrm{ABB}$ as dependent variable and species, number of shoots/branches and number of thorns as independent variables. The Duncan test was used to identify mean differences of 
variables among species. The allometric relationship between $\mathrm{ABB}$ and plant size was analyzed by a mixed model according to the generalized linear models procedure, with $\mathrm{ABB}$ as the response variable and species, basal diameter category $(\mathrm{cm})$, plant height category $(\mathrm{m})$, plant cover category $\left(\mathrm{m}^{2}\right)$ as fixed effects. To avoid the over dispersion of data, the model used a negative binomial distribution with a log link function. A Fisher test was used to assess differences among means. A correspondence analysis was performed to study the association of functional traits as ABB size (low, medium, high), growth habit, resprouting intensity and presence of thorns in disturbed and undisturbed forests. Statistical analyses were performed using Software Infostat.

\section{Results}

Table 1 shows average number of shoots and resprouts, number of thorns, length of thorns and $\mathrm{ABB}$ in the four studied species. The ANOVA indicated a significant effect on species, number of shoots and resprouts and number of thorns on ABB. Schinopsis lorentzii and $S$. fasciculatus had the greatest average ABB followed by S. mistol and A. quebracho-blanco $(p<0.05)$ allowing categorizing them the two first as high $\mathrm{ABB}$ species, the third as medium $\mathrm{ABB}$ species and the last as low ABB species. Both Anacardiaceae species did not show significant differences in $\mathrm{ABB}$ among them, but $S$. lorentzii had the greatest number of buds differentiated as branches or resprouts whereas in S. fasciculatus almost $50 \%$ of buds differentiated thorns. Aspidosperma quebracho-blanco represented the unique boneless species studied ( $p<0.05$; Table 1, Fig. 2). The three thorny species presented cauline thorns because they develop from axillary buds.

Schinus fasciculatus was the thorniest species and this species had conspicuous multinodal thorns with leaves and flowers in nodes becoming procumbent lateral branches, especially in 5-6 cm diameter individuals (Table 1, Fig. 2f). Sarcomphalus mistol has short, strong and conic uninodal thorns, without axillary appendices (Fig. 2e) and S. lorentzii develops strong isolated thorns. Schinus fasciculatus thorns presented the lengthiest thorns and $70 \%$ of them were ramified thorns (Table 1) whereas in S. mistol, $50 \%$ of individuals presented ramified thorns (Figs. 2e and 2f). The rank analysis of thorn length did not show significant differences among species and it was a highly variable trait among species and individuals of same species. Aspidosperma quebracho-blanco is a boneless species but its foliage is mucronate.

The mixed generalized model did not indicate correlation between plant diameter and ABB (Fig. 3a) but showed a significant negative correlation with plant height and plant cover (Table 2). All species diminished the $\mathrm{ABB}$ when plant height and plant cover increased (Figs. $3 \mathrm{~b}$ and 3c, Table 2). Schinus fasciculatus showed the lowest plant height and the greatest plant cover among studied species in congruence with its shrubby growth habit. Schinopsis lorentzii and S. mistol, high $\mathrm{ABB}$ and medium $\mathrm{ABB}$ species respectively, reached similar plant height and plant cover among greater size individuals where as Aspidosperma quebracho-blanco, a low ABB species, presented the lowest plant height and plant cover.

Table 1 Average plant height, number of branches or resprouts, number and length of thorns and average number of buds expressed as growth modules (ABB) in small size individuals of native woody species from Argentine Chaco region.

\begin{tabular}{lllll}
\hline Average & $\begin{array}{l}\text { Number of } \\
\text { branches/resprouts }\end{array}$ & Number of thorns & Length of thorns (cm) & ABB \\
\hline Schinopsis lorentzii & $45.6(15.8)^{\mathrm{a}}$ & $5.0(6.2)^{\mathrm{a}}$ & $2.1(0.5)$ & $50.6(16.4)^{\mathrm{a}}$ \\
Aspidosperma quebracho -blanco & $19.4(7.8)^{\mathrm{c}}$ & -- & - & $19.6(7.4)^{\mathrm{c}}$ \\
Sarcomphalus mistol & $35.0(13.0)^{\mathrm{b}}$ & $2.0(3.9)^{\mathrm{a}}$ & $2.0(1.6)$ & $37.0(12.5) \mathrm{b}$ \\
Schinus fasciculatus & $34.0(23.5)^{\mathrm{a}}$ & $13.7(19.2)^{\mathrm{b}}$ & $4.3(3.2)$ & $47.6(24.6)^{\mathrm{a}}$ \\
\hline
\end{tabular}

Different letters in columns indicate significant differences in Duncan's Tests $(p<0.05)$.

Standard deviations among brackets. 

Chaco in Response to Disturbances
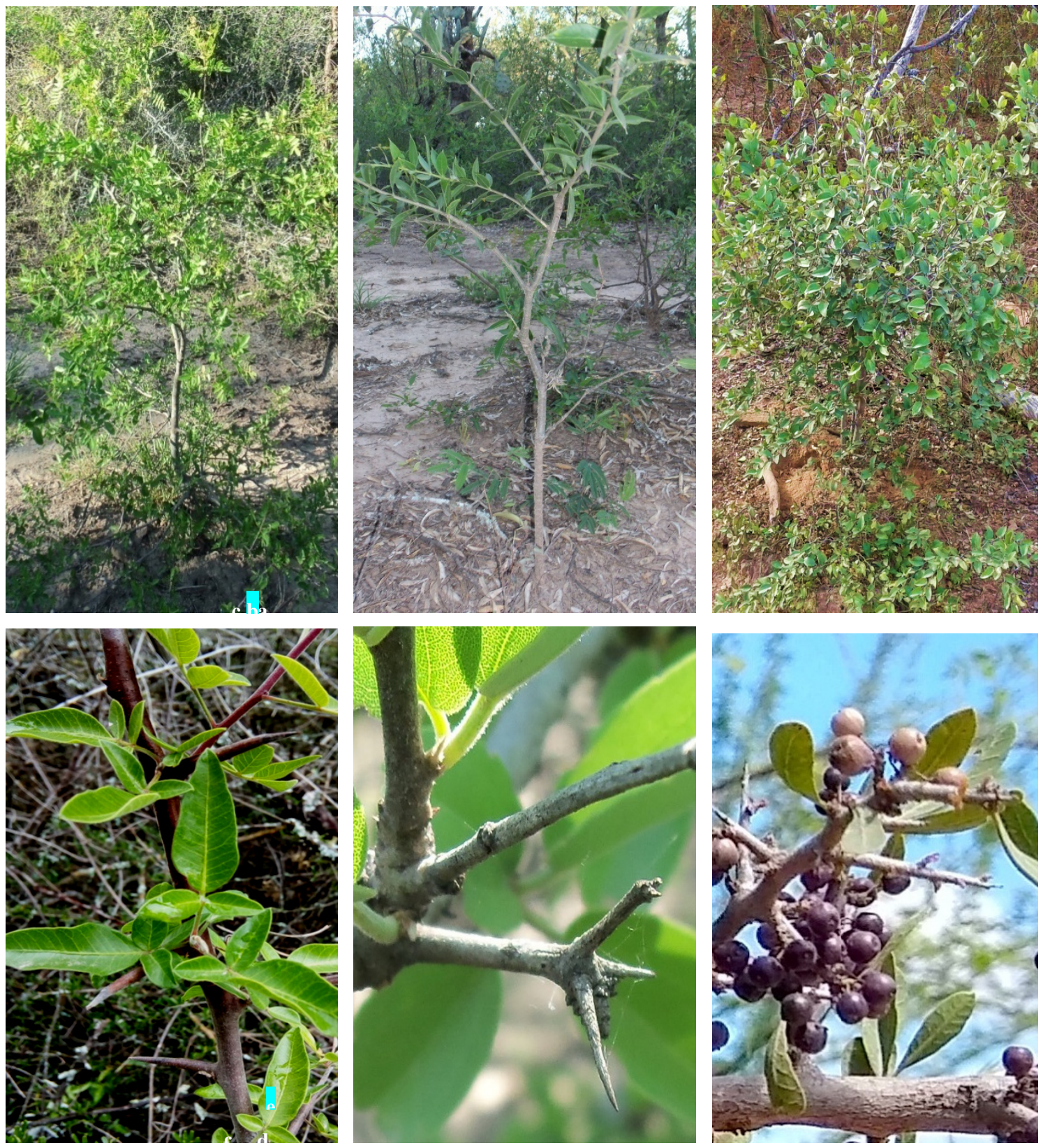

Fig. 2 Growth habit and different growth modules in small size individuals of woody species from Argentine Chaco forests. (a) Schinopsis lorentzii; (b) Aspidosperma quebracho-blanco; (c) Sarcomphalus mistol; (d) Thorns in S. lorentzii; (e) Thorns in S. mistol; (f) Multinodal thorns in Schinus fasciculatus. Letters of figures are missing.

The analysis of correspondence showed some associations between species functional traits (growth habit, $\mathrm{ABB}$, resprouting intensity and spinescence) in forests with different disturbance histories (Fig. 4). The axis 1 with inertia of $27.6 \%$ separated tree growth habit, null spinescence and null resprouting in non-disturbed forest plots (control) from shrubby growth habit, the presence of thorns and low and high resprouting intensity in disturbed forest plots.
The second axis with inertia of $21.53 \%$ separated species with high $\mathrm{ABB}$ in non-disturbed forest plots from the medium and low ABB tree species (A. quebracho-blanco and S. mistol) in disturbed forest plots. The contingency table analysis indicated that spinescence was the unique traits with significant association among types of forests $(p<0.0025$, Table 3) predominating thorny individuals in disturbed forests. 

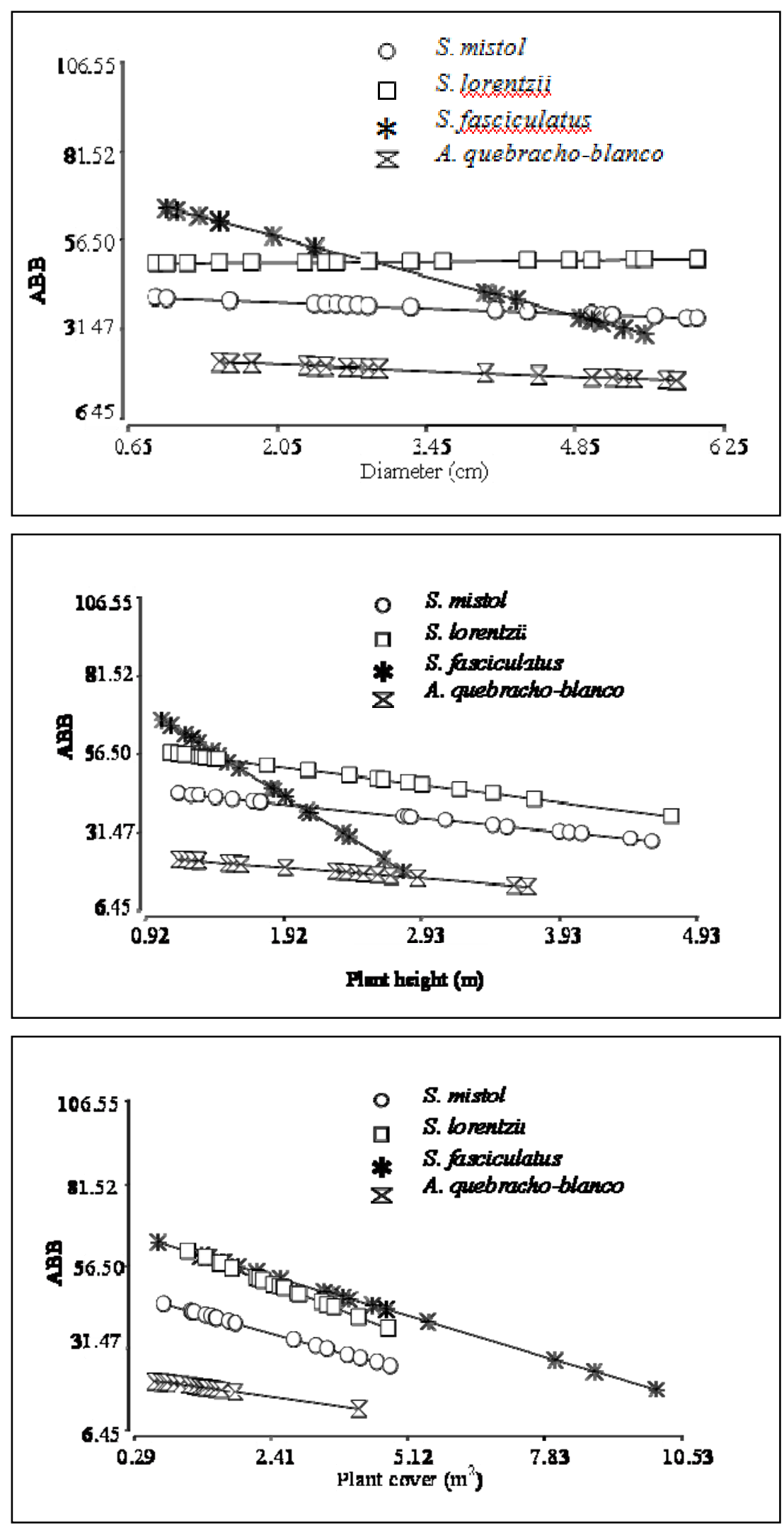

Fig. 3 Relationship between ABB, plant diameter (a), plant height (b) and plant cover (c) in juvenile individuals of Aspidosperma quebracho-blanco, Schinopsis lorentzii, Sarcomphalus mistol and Schinus fasciculatus. 
Table 2 Adjustment measures to the model of ABB with plant size variables (stem diameter, height and cover) in categories.

\begin{tabular}{lllll}
\hline No. & AIC & BIC & logLik & Deviance \\
80 & 646.33 & 682.06 & -308.16 & 81.60 \\
\hline & & DF & RD & $p$ \\
Species & 3 & 81.60 & $<0.0001$ \\
Plant diameter & 4 & 163.06 & 0.1322 \\
Plant height & 3 & 170.13 & 0.0006 \\
Diameter cover & 3 & 187.43 & $<0.0001$ \\
\hline
\end{tabular}

AIC: Akaike information criteria; BIC: Bayesioan information criteria; logLik: log likelihood.

\section{Discussions}

The approach used in this study allowed us to identify differences in $\mathrm{ABB}$ size among species studied in agreement with Klimešová, and Klimeš [2], Pelc, et al. [17] and Morisset, et al. [18] but it must consider an estimation of the $\mathrm{ABB}$ since the most axillary buds are frequently stored in perennial organs [2]. The higher proportion of buds differentiated in sprouts/resprouts could be considered the most distinctive feature of the tree species studied respect to $S$. fasciculatus, the shrubby specie. This species invests greater energy in defensive structures (thorns) due to its shrubby growth habit exposing its aerial structures to physical or mechanical disturbances as herbivory, fires, among others. However, the relative proportion of types of growth modules can vary with the growth habit, the herbivory intensity and other physical or mechanical damages.

The bud size and its localization are key traits to define resprouting among woody species [3, 6]. Despite the significant differences in $\mathrm{ABB}$ among studied species, all they exhibited high ability to resprout from epicormic buds despite the small size of plants. Schinopsis lorentzii, S. mistol and $A$. quebracho-blanco showed a high resprouting ability from subterranean organs and stems, in response to experimental fires and mechanical removal methods of native vegetation [13]. A profuse epicormic resprouting was observed in S. lorentzii, S. mistol whereas A. quebracho-blanco produced exclusively basal resprouts after low severity experimental burns [9]. Native woody species of Chaco Serrano forests resprouted mostly by buds located at the plant collar or in underground organs after fires [15]. However, these antecedents did not consider inter specific differences in the $\mathrm{ABB}$ size and its effects on the resprouting pattern.

In this work, the significant differences in the ABB size among studied species $(p<0.0001)$ seem to affirm our first hypothesis, and this aspect added to bark thickness should be considered when defining the woody species tolerance to physical or mechanical disturbances as wildfires, prescribed fires and roller-chopping as vegetation management techniques $[9,14]$. Schinopsis lorentzii and S. mistol were the tree species with greater resprouting ability than $A$. quebracho-blanco at least from epicormic buds in juvenile individuals, in agree with Bravo, et al. [9].

The high frequency of thorns in $S$. fasciculatus could be related to its shrubby habit and biotic stress by herbivory in the study area. The robust and multinodal thorns of this species could protect new shoots against herbivores and enhance its resprouting ability since they have buds in these short modified shoots. In this work, the number of buds in thorns was not considered. The length of thorns was the most variable traits among thorny species which avoided detecting a tendency. The formation of thorns can vary between populations, individual plants within a population, and in the same plant over time depending on, e.g., plant size, phenology, life-history state or previous browsing [26]. Schinopsis lorentzii has been described as a boneless species but juvenile individuals growing in areas disturbed by fires and livestock develop strong thorns in sprouts/resprouts protecting its highly palatable foliage. The lower number of thorns in S. lorentzii and S. mistol could be 


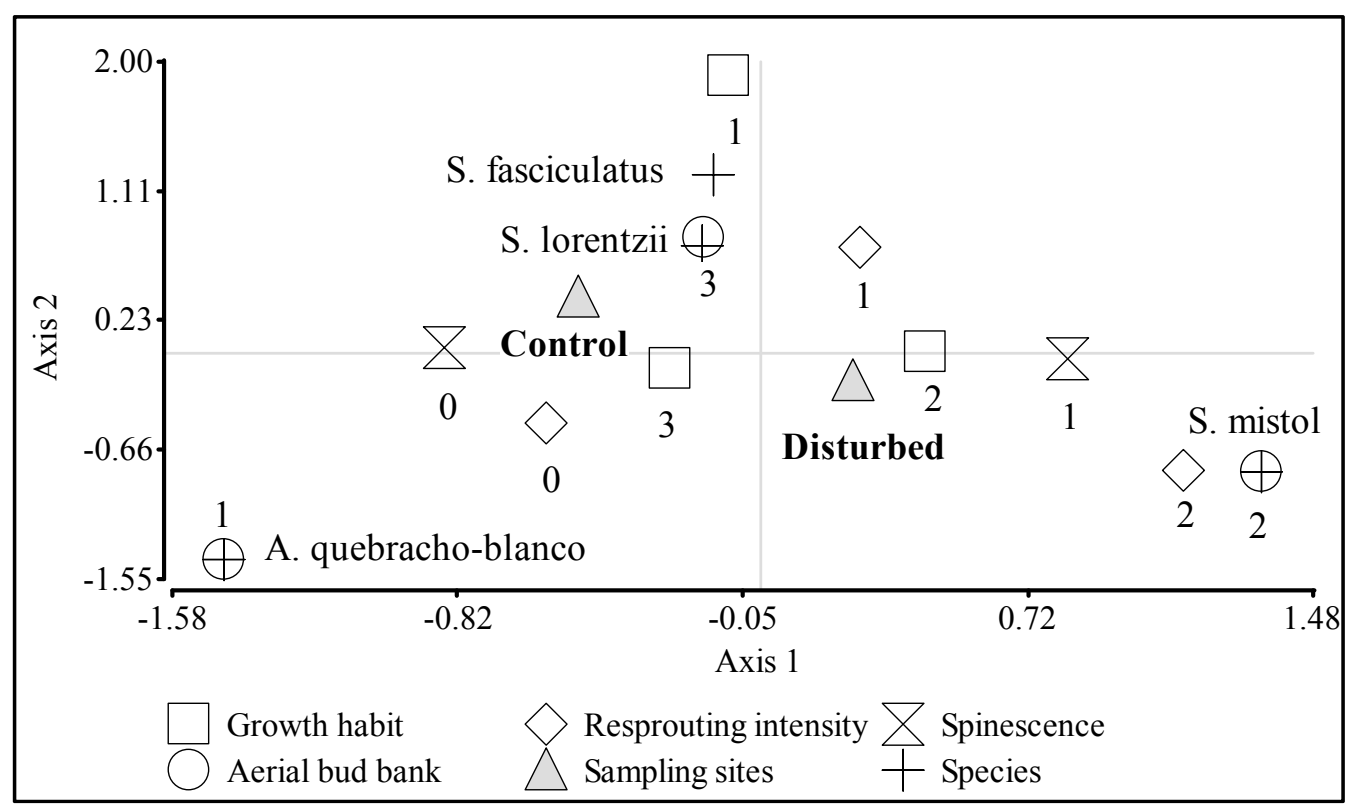

Fig. 4 Correspondence analysis among functional traits of four woody species, in Western Argentine Chaco forests with different disturbances histories.

Growth habit (1: subshrub, 2: shrub, 3: tree), ABB size (1: low in A. quebracho-blanco, 2: medium in $S$. mistol and 3: high in $S$. lorentzii and $S$. fasciculatus); resprouting intensity (0: null, 1: low, 2: high) and spinescence (0: null, 1: cauline thorns).

Table 3 Analysis of contingency tables with absolute frequencies of functional traits in native woody species in Chaco forests with different disturbance histories.

\begin{tabular}{|c|c|c|c|c|c|c|}
\hline Functional traits & Categories of trait & $\begin{array}{l}\text { Number } \\
\text { of individuals }\end{array}$ & Control forests & Disturbed forests & $\chi^{2}$ & $p$ \\
\hline \multirow{2}{*}{ Espinescence } & 0 & 31 & 16 & 15 & \multirow{2}{*}{9.18} & \multirow{2}{*}{0.0025} \\
\hline & 1 & 32 & 5 & 27 & & \\
\hline \multirow{3}{*}{$\begin{array}{l}\text { Resprouting } \\
\text { intensity }\end{array}$} & 0 & 28 & 9 & 19 & \multirow{3}{*}{2.25} & \multirow{3}{*}{0.3251} \\
\hline & 1 & 27 & 11 & 16 & & \\
\hline & 2 & 8 & 1 & 7 & & \\
\hline \multirow{3}{*}{ Growth habit } & 1 & 2 & 1 & 1 & \multirow{3}{*}{1.83} & \multirow{3}{*}{0.4015} \\
\hline & 2 & 22 & 5 & 17 & & \\
\hline & 3 & 39 & 15 & 24 & & \\
\hline \multirow{3}{*}{$\begin{array}{l}\text { Aerial bud bank } \\
\text { size }\end{array}$} & 1 & 11 & 4 & 7 & \multirow{3}{*}{2.08} & \multirow{3}{*}{0.354} \\
\hline & 2 & 16 & 3 & 13 & & \\
\hline & 3 & 36 & 14 & 22 & & \\
\hline
\end{tabular}

Growth habit (1: subshrub, 2: shrub, 3: tree), ABB size (1: low in A. quebracho-blanco, 2: medium in S. mistol and 3: high in $S$. lorentzii and S. fasciculatus); resprouting intensity (0: null, 1: low, 2: high) and spinescence (0: null, 1: cauline thorns).

related to the cost/benefit ratio of these structures in trees species [4].

The lower ABB size observed in all studied species when plants increased height and cover could be related to a greater allocation of carbohydrates reserves towards apical buds for lengthening of main shoots and branches, than to differentiation of new vegetative or defensive growth modules [3, 17]. Some authors considered that resprouting ability is usually higher at juvenile stage than mature stage [2, 17]. On other hand, Bond and Midgley [6] considered that resprouting ability increases with plant size until to reach a maximum at adult stage. Authors' results seem to reaffirm our second hypothesis since the ABB size of species studied diminished when average plant height and plant cover increased, even when this study is carried out in small size individuals. This size of plants allowed us to identify differences 
in ABB size among species studied, and it represents the more fragile stage (seedlings and juvenile individuals) in their lifespan. However, assessments of the $\mathrm{ABB}$ size in greater diameter individuals are desirable to improve this prediction. As well, the disturbance severity must be considered in this analysis [6,9].

Schinus fasciculatus is a high ABB shrubby species that showed the greatest plant cover among studied species. Disturbances affecting aerial plant structures could increase the initial plant cover through expression of buds in new shoots and thorns [2]. Therefore, management activities destined to shrubby stratum control by physical or mechanical methods [13] should consider the ABB size and resprouting ability from basal and underground organs, since these treatments could even increase the initial plant cover of shrubs [14, 27]. The intensive roller chopping application reduced exclusively the biomass of Larrea divaricata whereas it increased the number of individuals of Condalia microphylla and $S$. fasciculatus [28].

Although both axes of the analysis of correspondence of plant functional traits in forests with different disturbance history, explained less of $50 \%$ of variability of data, the disturbed forest plots were associated to the shrubby growth habit and resprouted and thorny plants. The maintenance of tree habit (without resprouting neither thorns) even in a high ABB species such as $S$. lorentzii in undisturbed forests seems to reaffirm that perturbations are the environmental forces promoting the expression of buds and architectural changes among studied species $[2,16,19,20,29]$. However, in authors' work, the spinescence is the single functional trait increased significantly in disturbed forests suggesting the investment of carbohydrates resources in defensive growth modules in these environments. The spinescence is a functional trait indicative of herbivory and dry environmental conditions [24]. Authors' results confirm partially the third hypothesis since the spinescence was the single trait with significant association with disturbed forests. The other functional traits related to architectural changes (growth habit, resprouting intensity) seem to need a quantitative study identifying the response to disturbances [30]. The significant relationship between spinescence and forest disturbances opens new questions about costs and benefits of the investment in defensive growth modules that could modify relative growth rate of species [4]. These aspects will be considered in future studies through quantitative analysis relating to disturbance intensity, resprouting pattern and architectural changes in native woody species from Chaco region.

\section{Conclusions}

Authors' results allowed identifying differences in the ABB size of juvenile individuals of woody species from Chaco region and enhancing the interpretation of the resprouting pattern observed after experimental burns among the tree species studied. Both Anacardiaceae species have high $\mathrm{ABB}$, and $S$. mistol and A. quebracho-blanco were the tree species with medium and low ABB size, respectively. Changes in growth habit, resprouting intensity and thorn presence were observed in the species studied in disturbed forests but the spinescence was the only trait that increases significantly in these environments. Authors' results should be considered in vegetation management plans such as silvopastoral systems in which the maintenance of tree architecture and the control of shrubby strata are desirable.

\section{Acknowledgements}

Authors are grateful to Science and Technology Council of National University of Santiago del Estero by the financial support of Project Assessment of Functional Groups of Native Woody Species from Argentine semiarid Chaco and responses to disturbances, and to Víctor Navarrete and José Godoy from INTA by logistic help in the field work. 


\section{References}

[1] Harper, J. 1977. Population Biology of Plants. New York: Academic Press.

[2] Klimešová, J., and Klimeš, L. 2007. "Bud Banks and Their Role in Vegetative Regeneration-A Literature Review and Proposal for Simple Classification and Assessment." Perspectives in Plant Ecology, Evolution and Systematic 8 (3):115-29.

[3] Clarke, P., Lawes, M., Midgley, J., Lamont, B., Ojeda, F., Burrows, G., and Knox, K. 2012. "Resprouting as a Key Functional Trait: How Buds, Protection and Resources Drive Persistence after Fire." New Phytologist 197 (1): 19-35.

[4] Tomlinson, K., Poorter, L., Bongers, F., Borghetti, F., Jacobs, L., and van Langevelde, F. 2014. "Relative Growth Rate Variation of Evergreen and Deciduous Savanna Tree Species Is Driven by Different Traits." Annals of Botany 114 (2): 315-24.

[5] Vesk, P., and Westoby, M. 2004. "Sprouting Ability across Diverse Disturbances and Vegetation Types Worldwide." Journal of Ecology 92: 310-20.

[6] Bond, W., and Midgley, J. 2001. "Ecology of Sprouting in Woody Plants: The Persistence Niche." Trends in Ecology and Evolution 16 (1): 45-51.

[7] Barchuk, A., Campos, E., Oviedo, C., and Díaz, M. 2006. "Supervivencia y crecimiento de plántulas de especies leñosas del Chaco Árido sometidas a remoción de la biomasa aérea." Ecologia Austral 16 (1): 47-61. (in Spanish)

[8] Lilly, C., Will, R., Tauer, C., Guldin, J., and Spetich, M. 2012. "Factors Affecting the Sprouting of Shortleaf Pine Rootstock Following Prescribed Fire.” Forest Ecology and Management 265: 13-9.

[9] Bravo, S., Kunst, C., Leiva, M., and Ledesma, R. 2014. "Response of Hardwood Tree Regeneration to Surface Fires, Western Chaco Region, Argentina." Forest Ecology and Management 326: 36-45.

[10] Boletta, P., Ravelo, A., Planchuelo, A., and Grilli, M. 2006. "Assessing Deforestation in the Argentine Chaco." Forest Ecology and Management 228 (1-3): 108-14.

[11] Bravo, S., Kunst, C., Grau, R., and Aráoz, E. 2010. "Fire-Rainfall Relationship in Argentine Chaco Savannas." Journal of Arid Environments 74: 1319-23.

[12] Torrella, S., Ginzburg, R., and Galetto, L. 2015. "Forest Fragmentation in the Argentine Chaco: Recruitment and Population Patterns of Dominant Tree Species." Plant Ecology 216 (11): 1499-510.

[13] Kunst, C., Ledesma, R., Bravo, S., Albanesi, A., Anriquez, A., Van Meer, H., and Godoy, J. 2012. "Disrupting Woody Steady States in the Chaco Region (Argentina): Responses to Combined Disturbance
Treatments." Ecological Engineering 42: 42-53.

[14] Ledesma, R., Kunst, C., Bravo, S., Leiva, M., Lorea, L., Godoy, J., and Navarrete, V. 2018. "Developing a Prescription for Brush Control in the Chaco Region, Effects of Combined Treatments on the Canopy of Three Native Shrub Species." Arid Land Research and Management $\quad 32 \quad$ (3): $\quad 1-16$. https://doi.org/10.1080/15324982.2018.1430072.

[15] Herrero, M., Torres, R., and Renison, D. 2015. "Do Wildfires Promote Woody Species Invasion in a Fire-Adapted Ecosystem? Post-fire Resprouting of Native and Non-native Woody Plants in Central Argentina." Environmental Management 57 (2): 308-17.

[16] UMSEF. 2003. "Parque Chaqueño." In Unidad de Manejo del Sistema de Evaluación Forestal. Secretaría de Ambiente y Desarrollo Sustentable de Argentina Editions. (in Spanish)

[17] Pelc, B., Montgomery, R., and Reich, P. 2011. "Frequency and Timing of Stem Removal Influence Corylus americana Resprout Vigor in Oak Savanna." Forest Ecology and Management 261 (1): 136-42.

[18] Morisset, J., Mothe, F., Bock, J., Bréda, N., and Colin, F. 2012. "Epicormic Ontogeny in Quercus petraea Constrains the Highly Plausible Control of Epicormic Sprouting by Water and Carbohydrates." Annals of Botany 109 (2): 365-77.

[19] Ky-Dembele, C., Tigabu, M., Bayala, J., Ouedraogo, S. J., and Oden, P. C. 2007. "The Relative Importance of Different Regeneration Mechanisms in a Selectively Cut Savanna-Woodland in Burkina Faso, West Africa." Forest Ecology and Management 243 (1): 28-38.

[20] Gómez, A., Kunst, C., and Navall, M. 2009. "Sistemas silvopastoriles en el Chaco semiárido II: Efecto del rolado sobre la regeneración natural de dos especies arbóreas nativas." In 1er. Congreso Nacional de Sistemas Silvopastoriles, edited by Ediciones INTA, p. 9. (in Spanish)

[21] Araujo, P., Iturre, M., Acosta, H., and Renolfi, R. 2008. "Estructura del bosque de La María EEA INTA Santiago del Estero." Quebracho 16: 5-19. (in Spanish)

[22] Kunst, C., Bravo, S., Ledesma, R., Navall, M., Anriquez, A., Coria, D., Silberman, J., Gómez, A., and Albanesi, A. 2014. "Ecology and Management of the Dry Forests and Savanna of the Western Chaco Region, Argentina." In Dry Forests Ecology, Species Diversity and Sustainable Management, edited by Greer, F. Nova Publishers.

[23] Tortorelli, L. 2009. Maderas y Bosques Argentinos, 2nd ed. Buenos Aires: Orientación Gráfica Editions.[24] Pérez-Harguindeguy, N., Díaz, S., Garnier, E., et al. 2013. "New Handbook for Standardized Measurement of Plant Functional Traits Worldwide." Australian Journal of Botany 61: 167-234. 
[24] Muller, S., Overbeck, G., Pfadenhauer, J., and Pillar, V. 2007. "Plant functional Types of Woody Species Related to Fire Disturbance in Forest-Grassland Ecotones." Plant Ecology 189: 1-14.

[25] Leife, H. 2010. "Has Woody Vegetation in a Semi-arid Savanna Changed after 11 Years Exclusion of Large Herbivores?" Tesis of Master Science, Department of Ecology and Genetics Plant Ecology, Uppsala University. $22 \mathrm{pp}$.

[26] Kunst, C., Navall, M., Ledesma, R., Silberman, J., Anríquez, A., Coria, D., et al. 2016. "Silvopastoral Systems in the Western Chaco Region, Argentina." In Silvopastoral Systems in Southern South America.
Advances in Agroforestry, No. 11, edited by Peri, P., Dube, A., and Varella. Berlin: Springer International Publishers.

[27] Bogino, S., and Bravo, M. 2014. "Impacto del rolado sobre la biodiversidad de especies leñosas y la biomasa individual de jarilla (Larrea divaricata) en el Chaco Árido Argentino." Quebracho 22 (1, 2): 79-87.

[28] Pausas, J., and Keeley, G. 2014. "Evolutionary Ecology of Resprouting and Seeding in Fire-Prone Ecosystems." New Phytologist 204 (1): 55-65.

[29] Zizka, A., Navashni, G., and Higgins, S. 2014. "How to Tell a Shrub from a Tree: A Life-History Perspective from a South African Savanna.” Austral Ecology 39: 767-78. 